\title{
Recruiting Women in IT: A Conjoint-Analysis Approach
}

\author{
Marvin Schuth \\ Technical University of Munich \\ marvin.schuth@tum.de
}

\author{
Prisca Brosi \\ Technical University of Munich \\ brosi@tum.de
}

\author{
Isabell M. Welpe \\ Technical University of Munich \\ welpe@tum.de
}

\begin{abstract}
The war for talent in the fields of information systems (IS) and information technology (IT) has intensified over the last years. Especially the attraction of skilled women to compensate for higher demands and to bring in different perspectives and diverse expertise has become a challenging task for organizations. So far, literature suggested promoting special female programs and a balanced work-family culture to attract more women to IT omitting that women may also seek general career characteristics such as salary and benefits, career advancement and promotion opportunities, and challenging tasks. By using an experimental conjoint design with 101 female and 115 male IT-professionals, we simultaneously tested and compared the effects of these factors on the intention to apply for an IT-related position. The results suggest that both female and male ITprofessionals value work-family balance as the most important characteristic followed by general career characteristics while mentoring programs for women appeared as least important.
\end{abstract}

\section{Introduction}

Information technology is expected to be the essential driver of competitiveness, innovation, and productivity [10, 74]. According to the U.S. Bureau of Labor Statistics, occupations in computer and information technology are expected to grow by 12 percent from 2014 to 2024 adding about 488,500 jobs, "faster than the average for all occupations" [7]. Consequently, organizations and politics have reinforced their investments in attracting IT students and professionals. In addition, interests in hiring and retaining potential employees have received considerable attention in recruitment literature $[9,17$, 62] and from researchers in other scientific fields such as information systems and psychology [18, 34].

The general gap of qualified IT-workers in North America and Europe could partially be filled by attracting women to IT jobs [53, 74]. Country-level data such as from the U.S. (24 percent), Sweden (22 percent), Canada (22 percent), the United Kingdom (18 percent), and Germany (15 percent) $[12,21]$ consistently shows that women are vastly underrepresented in IT-jobs. In comparison, women make up to at least 50 percent of the labor force in each of these countries [12,21]. Attracting women to these jobs may not only help to fill the gap but also bring in different perspectives that could refine software as well as hardware concepts [49]. This is particularly important as companies often fail to address women's needs and challenges in designing and advertising products and services despite women accounting for a significant amount of users and customers (e.g. $42 \%$ of active game players are women [25]) [40, 49].

Recent recruitment research on how to attract more women to IT has stated that women-oriented career characteristics such as mentoring programs for women [56] and work-family balance [28] may inspire women to apply for IT-jobs. Yet, women are also often disadvantaged in general career characteristics such as salary and benefits [39], career advancement and promotion opportunities, and challenging tasks [33], which may render these characteristics as particularly desirable. Most prior studies, so far, were focused on only one of these characteristics failing to compare the importance of career characteristics [24, 27, 28]. Applicants, however, evaluate several career characteristics simultaneously in applying for a position [45], making it crucial to understand which characteristic ultimately drives attraction of IT jobs. Thus, there is an urgent need to investigate these characteristics in combination regarding their effects on intention to apply for an IT-related position [11, 15].

We address this need for research by applying experimental conjoint analysis, an analytical technique adapted from marketing and herein used to measure the relative importance of particular career characteristics [9]. Thereby, we contribute to recruitment research in information technology in two ways. First, we advance research on applicant attraction by simultaneously examining and comparing the effects of womenoriented as well general career characteristics [9]. Second, by scrutinizing gender effects in attraction to IT jobs we also contribute to research on gender and 
IS/IT [48, 72] by challenging if women indeed react differently on career characteristics than men.

We will draw practical conclusions for human resource management in IT by suggesting which content is most important in advertising IT jobs to increase the attraction of IT jobs for female applicants.

\section{Theory and research questions}

\subsection{Signaling Theory}

In recruitment literature, signaling theory is of pivotal importance [8, 9]. Within this concept, a potential applicant (receiver) assesses provided information (signals) in evaluating job advertisements of organizations (signaler).

Signaling theory further suggests that applicants exploit the information that is provided at the initial stage of the recruitment process to screen out specific alternatives [71]. Hence, organizations aim to send out advantageous signals about characteristics that heighten applicant attraction [7, 31, 73].

Women and men, however, may be attracted by different career-related signals or, at least, weight them differently [19, 32]. Thus, the signals provided by women-oriented and general career characteristics such as mentoring programs for women, work-family culture, salary and benefits, career advancement and promotion opportunities, and challenging tasks may have different weights in attracting female and male IT-professionals [2, 34, 60].

\subsection{Mentoring programs for women}

Mentoring refers to sponsoring, coaching, protection, confirmation, visibility, and role modeling by an experienced mentor to provide career and psychological support to a mentee [4, 44]. Considering the critical influence of mentoring on career development [4], organizations often encourage their employees to engage in mentoring relationships. In this vein, mentoring programs have become a standard management tool to facilitate individual success [4].

Regarding women in IT, several authors have stated that specific mentoring programs for women may be necessary to provide adequate support for female employees $[2,22,49]$. They have argued that given a male-dominated, competitive, and self-absorbed environment in IT, women may have difficulties to find adequate mentors providing them with role modeling [49]. Further, women often self-select themselves or are allocated into caretaking positions [47] which, in turn, compromises women's career opportunities [5]. Moreover, as women have been found to rely more on personal relationships for career development than men [65], special mentoring programs for women may increase women's career opportunities in IT [69]. Considering their proposed positive outcomes, women may be attracted to IT organizations that provide women specific mentoring programs.

Whereas mentoring programs for women are generally seen as being beneficial for the attraction of female applicants, the signaling effect on potential male applicants appears to be unknown. On the one hand, women-oriented mentoring programs may trigger in-group behavior [16] leading men to avoid organizations for signaling special treatments for women. On the other hand, men may support the effort of bringing in more women to IT as they see the positive effects of diversity in the workforce [63].

\subsection{Work-family culture}

Work-family culture is defined as an organization's values, beliefs, and support regarding the integration of employees' family lives and work responsibilities [67]. More specific, work-family culture refers to organizational time demands and attitudes such as long working hours [57], negative consequences for prioritizing family over work [58], and sensitivity for family-related responsibilities [66].

The IT environment is associated with long work hours, late nights, and on-call services including travel [3]. Thus, working in IT was found to elicit conflicts between work demands and family responsibilities [2]. In contrast, women are assumed to and have shown to be focused on family and children [2]. Especially at earlier career stages, female professionals are confronted with managing their careers and family lives [2]. Consequently, working in IT may imply a double bind for women either sacrificing their future careers by starting a family or neglecting their responsibilities to their families by aiming for a professional career [49]. Thus, communicate a family friendly culture may help to attract women to IT.

Recent research has shown that men, similar to women, are concerned with work-family balance in IT [3]. As dual-career marriages are becoming more common [59], men may also value family friendly organizational structures in IT companies. Signaling a well-balanced work-family culture may thus also attract male applicants in IT [45].

\subsection{Salary and benefits}

Financial rewards usually refer to an overall earning package for employees including base salary, 
bonus payments, and additional benefits such as stock options [51].

With regard to attracting women to IT, scholars have argued that women on average receive less salary and benefits than their male colleagues [2]. According to Panteli et al. [55], career breaks and part-time work due to family responsibilities may be main drivers for this gap. Yet, research also indicates that the gender pay gap is rarely warranted by performance differences [39]. Thus, signaling a focus on financial rewards may attract women to apply for an IT-position.

In addition to earning more than their female colleagues, men in IT are also assumed to being more concerned with payment aspects as they generally see themselves as breadwinners [45, 55]. Hence, male IT professionals may likewise be attracted by financial rewards.

\subsection{Career advancement and promotion opportunities}

Career advancement and promotion opportunities can be described as the extent of developmental opportunities to gain responsibility and strengthen personal skills [43]. Training, encouragement for advancement, and continuing education, amongst other determinants, have been found to be essential for career advancements in organizations [29].

Similar to salary and benefits, professional women in IT were found to receive less career advancement and promotion opportunities than men [2]. Again, a male-dominated environment and lack of role models may hinder women from receiving opportunities for advancement and promotion in IT [2, 38]. Signaling opportunities for career advancement and promotion may therefore also attract women to IT jobs.

This phenomenon is not applicable to men, as they are frequently encouraged to improve their IT-skills and were also found to receive more promotions than women [37]. Nevertheless, career advancement and promotion opportunities are linked to future work assignments [68], career success, and rewards [52]. Thus, signaling high career advancement and promotion opportunities can be assumed to have a positive effect on job attraction for men.

\subsection{Challenging tasks}

Challenging job demands can serve as intrinsic motivators in organizational settings. For instance, forcing employees to make decisions and solve problematic tasks under uncertain circumstances, onthe-job challenges can stimulate performance and personal development [54].
Regarding women in IT, working on challenging tasks has been found to be "very important" in choosing a job [55]. Challenging tasks may be especially important for women as research shows that they are more often assigned to less challenging work assignments than men [42] which, in turn, can hurt their career development [20]. Therefore, signals of challenging tasks may increase job attractiveness for women.

In contrast, their male colleagues are expected to solve difficult jobs, which leads to them being staffed on more challenging tasks [33]. In any case, challenging tasks are the basis of intrinsic motivation [42]. Thus, men may value the signal of challenging tasks in applying for an IT-position as well.

\subsection{Formulation of hypothesis and research questions}

In sum, we found arguments that both womenoriented career characteristics, i.e., mentoring programs for women and work-family culture, and general career characteristics, i.e., salary and benefits, career advancement and promotion opportunities, and challenging tasks, can signal to women and men that an IT- position is attractive.

H1: 1) Mentoring programs for women, 2) workfamily culture, 3) salary and benefits, 4) career advancement and promotion opportunities, and 5) challenging tasks have a positive influence on intention to apply for an IT-related position for women and men.

Yet, in line with women and men generally differing in their preferences for career characteristics [43], we also found different reasons why womenoriented and general career characteristics are important for women and men. Therefore, female and male IT-professionals may also differ in the extent to which these characteristics influence their intention to apply for an IT-related position.

RQ1: Are there gender differences in the extent to which 1) mentoring programs for women, 2) workfamily culture, 3) salary and benefits, 4) career advancement and promotion opportunities, and 5) challenging tasks have a positive influence on intention to apply for an IT-related position?

Also resulting from the differences in reasoning why women-oriented and general career characteristics are important for women and men, arises the question about which characteristics are most important for women and men. Thus, even when all characteristics increase job attractiveness for both women and men, differing strengths of the effects may lead to a different ranking of the characteristics for women and men.

RQ2: Which are the most important career characteristics for women and men? 


\section{Method, sample, and measurement}

Applying an experimental conjoint design, we asked participants to evaluate descriptions of job postings regarding their intention to apply for an unspecific IT-related position.

The participants were presented with vignettes to assess intention to apply for an IT-related position. By requiring participants to evaluate vignettes that depict a combination of characteristics, experimental conjoint design facilitates the understanding of causal relationships in providing a more realistic decisionmaking scenario and simultaneously enables to manipulate and control independent variables, thereby improving internal and external validity $[1,6]$.

The five characteristics 1) mentoring programs for women, 2) work-family culture, 3) salary and benefits, 4) career advancement and promotion opportunities, and 5) challenging tasks were manipulated on two levels each, as depicted in Table 1. An orthogonal design was applied to reduce the number of vignettes and, thereby, avoiding overload for participants. In this way, the initial $2 * 2 * 2 * 2 * 2$ matrix was compressed to eight vignettes. To account for order effects, the vignettes were presented in random order.

Table 1. Levels of characteristics

\begin{tabular}{lcc}
\hline \multicolumn{1}{c}{ Characteristic } & Low Level & High Level \\
\hline Mentoring for women & $\begin{array}{c}\text { hardly } \\
\text { available }\end{array}$ & $\begin{array}{c}\text { broadly } \\
\text { available }\end{array}$ \\
Work-family culture & very poor & very good \\
Salary and benefits & no focus on & focus on \\
Career advancement & very low & very high \\
Challenging tasks & very low & very high \\
\hline
\end{tabular}

Mentoring for women $=$ Mentoring programs for women; Career advancement $=$ Career advancement and promotion opportunities

\subsection{Sample}

Data was collected between December 2016 and January 2017 using an online survey. The sample consisted of 216 professionals currently working in or with experience in IT and IT-related jobs, including 101 women and 115 men of different origin. Most participants were German (37\%), of another European origin (31\%), or Asian (12\%). Participants' age ranged from 23 to 61 , with a mean of $38.71(S D=9.24)$. Most participants had a university degree with $58 \%$ having a master degree or similar equivalent and $21 \%$ having a bachelor degree or similar equivalent.

\subsection{Induction and measurements}

At the beginning of the conjoint experiment, participants were shown a brief description of each of the five characteristics. Within the vignettes, each characteristic was presented at one of two levels [45]. Vignettes were developed according to best practice examples [6]. A sample vignette is presented in Figure 1.

Following each job posting, participants were asked to rate their intention to apply for the position on an 11-point scale ranging from 0 to $100 \%$ [23]. Scale anchors were, $0 \%$ - I would definitely not apply and $100 \%$ - I would definitely apply. Within experimental vignette designs, one-item measures are frequently used to avoid overloading for the participants [6].

Participant sex was coded male (0) and female (1). We controlled for age since career preferences have been found to change within peoples' lifetime and, thus, affect participant attraction [43]. Applicant age was given in years.

In addition, we controlled for job satisfaction as satisfaction with current workplace situation has been found to influence employers' information processing regarding job postings [43]. We used the three-item measure from the Michigan Organizational Assessment Questionnaire [14] to assess global job satisfaction. Participants responded on a 7-point Likert scale ranging from (1) - strongly disagree to (7) - strongly agree. Internal consistency reliability for this measure was .77 .

\subsection{Analytical strategy}

The orthogonal design of our conjoint experiment resulted with eight ratings from 216 participants in 1.728 total observations. Because the data were nested within individuals, we applied a random effects regression model [61, 64]. Standardized regression coefficients were compared by calculating 95\% confidence intervals for each coefficient. They are expected to be significantly different when they do not lie within each other's confidence intervals [41]. When controlling for age and job satisfaction, data were analyzed using a subsample of 1.664 observations as eight participants did not indicate their age.

\section{Results}

Descriptive characteristics and correlations for between-person differences are presented in Table 2. 


Organization $\mathbf{A}$ is focused on the following characteristics promoting an IT-related position.
$\begin{array}{lc}\text { Criteria } & \text { Characteristic } \\ \text { Salary and benefits } & \text { No focus } \\ \text { Mentoring programs for women } & \text { Broadly available } \\ \text { Career advancement and promotion opportunities } & \text { Fully given } \\ \text { Challenge } & \text { Very low Very good } \\ \text { Work-family culture } & \text { Ven }\end{array}$

\section{Figure 1. Sample Vignette}

We first investigated $\mathrm{H} 1$ according to which we expected positive effects on intention to apply for an IT-related position for all five characteristics. The analysis revealed positive and significant coefficients for women and men regarding all five characteristics, as depicted in Table 3. Thus, H1 was supported for all characteristics for women and men.

Next, we examined RQ1, which asked for differences between women and men in the positive effects of the five characteristics on intention to apply for an IT-related position. Results are depicted in Table 4. Controlling for age and job satisfaction, moderation analyses revealed no significant influence of sex on the positive relation between any of the five career characteristics and intention to apply for an IT-related position.

Finally, we examined RQ2 asking which characteristics were most important for women and men. For women, results revealed the following rankorder: 1) work-family culture, 2) career advancement, 3) challenging tasks, 4) salary and benefits, and 5) mentoring for women. The effect of work-family culture was significantly stronger than the effects of challenging tasks, salary and benefits, and mentoring for women, while the effect of mentoring for women was significantly smaller than all other effects. No significant differences resulted between effects of career advancement, challenging tasks, and salary and benefits. For men, the rank-order resulted to be: 1) work-family culture, 2) salary and benefits, 3) challenging tasks, 4) career advancement, and 5) mentoring for women. The effect of work-family culture was significantly stronger than the effects of challenging tasks, career advancement, and mentoring for women, while the effect of mentoring for women was significantly smaller than all other effects. The effect of salary and benefits was also significantly larger than the effects of challenging tasks and career advancement

\section{Discussion}

The overall results of our study suggest that female and male IT-professionals are more similar than different in their perception of favorable career characteristics in applying for an IT-position.

All job characteristics had a positive effect on intention to apply for an IT-related position for women and men. In addition, results did not indicate differences in the positive effects for the five career characteristics between women and men. This is noteworthy, as mentoring programs for women are especially designed for increasing the attraction of women, but not for men [49]. Further, for women and men, work-family culture was most important and mentoring programs for women was least important with the general job characteristics landing in between.

Table 2. Correlation matrix

\begin{tabular}{lccccccccc}
\hline & $M$ & $S D$ & $M I N$ & $M A X$ & 1. & 2. & 3. & 4. & 5. \\
\hline 1. Sex & 0.47 & 0.50 & - & - & - & & & & \\
2. Age & 38.71 & 9.24 & 23.00 & 61.00 & $-.27^{* * *}$ & - & & & \\
3. Degree & 3.58 & 0.88 & 1.00 & 6.00 & .06 & .02 & - & & \\
4. Job satisfaction & 5.71 & 1.14 & 2.00 & 7.00 & $.06^{* *}$ & -.04 & -.04 & $(0.77)$ & \\
5. Intention to apply & 4.65 & 3.12 & 1.00 & 11.00 & .02 & -.05 & $.06^{*}$ & -.03 & -
\end{tabular}

$N=1,728$ (216 participants); levels of significance for correlations between variables 1-4 are based on number of participants (216), levels of significance for correlations with variable 5 are based on number of ratings $(1,728)$; sex was coded with $0=$ male and $1=$ female; degree was coded with $1=$ Secondary school, $2=$ High school, $3=$ Bachelor, $4=$ Master/Diploma (and similar), $5=\mathrm{PhD}, 6=$ Professorship; Cronbach's alpha on the diagonal in parentheses; ${ }^{*} p<.05, * * p<.01, * * * p<.001$ 
Table 3. Comparison of job characteristics

\begin{tabular}{|c|c|c|c|c|c|c|c|c|c|}
\hline & \multicolumn{3}{|c|}{ Total } & \multicolumn{3}{|c|}{ Women } & \multicolumn{3}{|c|}{ Men } \\
\hline & $\beta$ & $\begin{array}{l}95 \% \\
L L C I\end{array}$ & $\begin{array}{l}95 \% \\
U L C I\end{array}$ & $\beta$ & $\begin{array}{l}95 \% \\
L L C I\end{array}$ & $\begin{array}{l}95 \% \\
U L C I\end{array}$ & $\beta$ & $\begin{array}{l}95 \% \\
L L C I\end{array}$ & $\begin{array}{l}95 \% \\
\text { ULCI }\end{array}$ \\
\hline Work-family culture & $0.367 * * *$ & 0.336 & 0.398 & $0.366^{* * * *}$ & 0.321 & 0.410 & $0.368 * * *$ & 0.326 & 0.410 \\
\hline Salary and benefits & $0.313 * * *$ & 0.282 & 0.343 & $0.293 * * *$ & 0.249 & 0.338 & $0.330 * * *$ & 0.288 & 0.372 \\
\hline Challenging tasks & $0.291 * * *$ & 0.260 & 0.322 & $0.302 * * *$ & 0.258 & 0.347 & $0.281 * * *$ & 0.239 & 0.323 \\
\hline Career advancement & $0.291 * * *$ & 0.260 & 0.321 & $0.326^{* * *}$ & 0.281 & 0.370 & $0.259 * * *$ & 0.218 & 0.301 \\
\hline Mentoring for women & $0.195^{* * *}$ & 0.165 & 0.226 & $0.220 * * *$ & 0.175 & 0.264 & $0.173 * * *$ & 0.131 & 0.215 \\
\hline$R^{2}$ & 0.440 & & & 0.465 & & & 0.421 & & \\
\hline
\end{tabular}

$N=1,728$ (216 participants); $L L C I=$ lower limit confidence interval, $U L C I=$ upper limit confidence interval; Mentoring for women $=$ Mentoring programs for women; Career advancement $=$ Career advancement and promotion opportunities; $* p<.05, * * p<.01, * * * p<.001$

Only slight gender differences resulted in the ranking of the general job characteristics. While for women, career advancement and promotion opportunities followed work-family culture with these effects not being significantly different, for men workfamily culture was followed by salary and benefits with these effects neither being significantly different.

These results rather support the gender similarities hypothesis [36] which states that women and men are more alike, but not different, on most psychological variables [35] and especially on preferences for job characteristic [43]. Also explaining similar career preferences, women and men in IT could internalize a set of similar norms and values because of identification and commitment with their profession [43]. Rated highest by women and men, the overall importance of work-family culture further indicates a possible break-up of traditional gender roles in the context of IT professions [48].

\subsection{Theoretical contribution}

With these results, we contribute to existing literature in the following ways. We add to research on career determinants in IT [18] by providing empirical evidence on the positive signals of work-family culture, salary and benefits, career advancement and promotion opportunities, challenging tasks, and mentoring programs for women.

Further, our results contribute to gender and IS/IT research in suggesting that men and women in IT are more similar in their perceptions of favorable career characteristics than hitherto expected [48]. Literature has argued that women in IT face different careerrelated barriers [2], increasing the need for organizations to signal women-oriented career characteristics to be attractive for female applicants
[49]. Within our sample, however, applicant sex had no influence on the relation between any of the career characteristics and intention to apply for an IT-related position, indicating that women in IT prefer similar career characteristics as their male colleagues.

Identifying work-family culture as the most important characteristic for both, women and men, our research emphasizes the importance of a balance between work responsibilities and family time in ITprofessionals' career motivations $[38,60]$. Although previous research already showed the importance of family-supportive cultures on female IT-professionals [48], our findings indicate that work-family culture is not only the most important career characteristic for women but also for men. These indications highlight the notion that work-family culture must be seen as a general rather than a women-oriented career characteristic [33]. This, in turn, indicates that the classical understanding of men being more careeroriented and less family-oriented than women may be outdated [33].

Comparing the importance of mentoring programs for women with other career-related characteristics, in research on recruiting and retaining women in IT [49], our study advances research on the assumption that mentoring programs for women may help to attract women to IT [27]. Although mentoring programs for women had a positive effect, it was smaller compared to all other characteristics, which puts corporate practice to advertise their jobs with women-oriented programs under question.

Finally, as mentoring programs for women also had a small yet positive influence on men's intention to apply, we contribute to literature on diversity in IT by suggesting that men indeed value interventions to increase workforce diversity [63]. 
Table 4. Regression predicting intention to apply for IT-position

\begin{tabular}{|c|c|c|}
\hline Variable & Model 1 & Model 2 \\
\hline Work-family culture & $0.368 * * *$ & $0.368 * * *$ \\
\hline Salary and benefits & $0.310 * * *$ & $0.310 * * *$ \\
\hline Challenging tasks & $0.296 * * *$ & $0.296 * * *$ \\
\hline Career advancement & $0.292 * * *$ & $0.292 * * *$ \\
\hline Mentoring for women & $0.193 * * *$ & $0.193 * * *$ \\
\hline Age & -0.047 & -0.046 \\
\hline Job satisfaction & -0.028 & -0.028 \\
\hline Sex & & 0.006 \\
\hline Work-family culture $\times$ Age & 0.002 & 0.003 \\
\hline Salary and benefits $\times$ Age & -0.013 & -0.019 \\
\hline Challenging tasks $\times$ Age & 0.018 & 0.024 \\
\hline Career advancement $\times$ Age & -0.030 & -0.024 \\
\hline Mentoring for women $\times$ Age & 0.004 & 0.012 \\
\hline Work-family culture $\times$ Job sat. & 0.015 & 0.014 \\
\hline Salary and benefits $\times$ Job sat. & $0.033^{*}$ & $0.035^{*}$ \\
\hline Challenging tasks $\times$ Job sat. & 0.008 & 0.006 \\
\hline Career advancement $\times$ Job sat. & 0.024 & 0.022 \\
\hline Mentoring for women $\times$ Job sat. & $0.038^{*}$ & $0.036^{*}$ \\
\hline Work-family culture $\times$ Sex & & 0.003 \\
\hline Salary and benefits $\times$ Sex & & -0.024 \\
\hline Challenging tasks $\times$ Sex & & 0.022 \\
\hline Career advancement $\times \operatorname{Sex}$ & & 0.024 \\
\hline Mentoring for women $\times$ Sex & & 0.029 \\
\hline$R^{2}$ & 0.445 & 0.449 \\
\hline \multicolumn{3}{|c|}{$\begin{array}{l}N_{\text {Model }} 12 / 3=1,664 \quad(208 \text { participants }) ; \text { table shows } \\
\text { standardized coefficients; sex was coded with } 0=\text { male and } 1 \\
=\text { female; Mentoring for women = Mentoring programs for } \\
\text { women; Career advancement = Career advancement and } \\
\text { promotion opportunities; Job sat. = Job satisfaction; } \\
* p<.05, * * p<.01, * * * p<.001\end{array}$} \\
\hline
\end{tabular}

\subsection{Limitations and future research}

Despite applying an experimental conjoint approach the current study has some limitations, which should be addressed by future research. First, the intention to apply for an IT-related position was hypothetical and based on signals about job characteristics in simplified job postings. Yet, and despite the use of self-reporting and social biases resulting from signaling career characteristics, research has shown that conjoint results are consistent with reallife settings [50]. Further, supporting the use of signaling theory even in real-life settings potential applicants may have limited information in applying for a position [70]. Nevertheless, future research should examine the job characteristics in actually experienced decisions to apply for a job.

Second, due to reasons of practicability and potential overload, we limited our list to five job characteristics that were directly linked to attraction of women in IT. The positive effect of all five characteristics on intention to apply generally emphasizes their importance regarding the attraction of IT-professionals. Nevertheless, potential applicants may also be attracted by additional job or organizational characteristics such as work climate, job security, and social interaction as these aspects have been found to influence applicant attraction of ITstudents [45]. Further, a more fine-grained view detailing, for example, human resource management approaches to work-family culture such as promoting different levels of flextime and flexplace [48, 67] may provide a deeper understanding on recruiting and retaining IT professionals. Future research in the form of qualitative approaches may include these additional workplace factors and human management approaches to determine applicant attraction and women and men's career advancement in IT.

Third, questions on the generalizability of our results may be raised due to research having shown that geographical differences influence job characteristic preferences of respondents [13]. Although our sample included participants from different origins future examinations may address if, for example, cultural values such as power distance [26] or socio-economic factors such as income-levels [9] may influence the signaling effect of career characteristics. Additionally, individual differences other than gender may influence the attractiveness of IT jobs. Future studies may examine if, for example, employees with strong preferences towards regular working hours and a balanced work-life culture [30] may value work-family culture even more or general career characteristics less.

Fourth, investigating professionals with an ITrelated background our findings may be different for respondents in particular IT jobs such as data scientist or software developers or on different career stages such as IT students. More specific studies in this field are needed to examine potential differences between the various IT jobs. Moreover, signaling career-related characteristics may also be important for applicant attraction in other professions aside from IT. For example, technical and male-dominated environments 
such as engineering have been found to have difficulties in attracting women [10]. Thus, researchers may also apply our approach to identify important drivers for applicant attraction in other professions.

\subsection{Implications for organizations}

The results of this study provide important insights for the recruitment and attraction of female and male IT-professionals. First, organizations should place a particular emphasis on a family friendly culture to attract both, women and men. This is even more crucial, as working in IT has been assumed to elicit work-family conflicts [3]. Second, organizations should highlight career-related characteristics in their human resource activities with career advancement and promotion opportunities being particularly important for women. Third, although mentoring for women is not the primary factor for the attraction of female applicants, IT-companies should not fear to promote special female programs as women and men may consider such programs as beneficial.

Signaling favorable career characteristics, however, is only successful if carefully integrated into an organization's overall recruitment and communication strategy [46]. Consequently, our results may encourage organizations to establish targeted strategies for the attraction and retention of female and male IT professionals.

\section{References}

[1] Aguinis, H. and Bradley, K. J., "Best Practice Recommendations for Designing and Implementing Experimental Vignette Methodology Studies", Organizational Research Methods 17(4), 2014, pp. 351-371.

[2] Ahuja, M. K., "Women in the information technology profession: A literature review, synthesis and research agenda", European Journal of Information Systems 11(1), 2002, pp. 20-34.

[3] Ahuja, M. K., Chudoba, K. M., Kacmar, C. J., McKnight, D. H., and George, J. F., "IT Road Warriors: Balancing Work-Family Conflict, Job Autonomy, and Work Overload to Mitigate Turnover Intentions", MIS Quarterly 31(1), 2007, pp. 1-17.

[4] Allen, T. D., Eby, L. T., Poteet, M. L., Lentz, E., and Lima, L., "Career benefits associated with mentoring for protégeé: a meta-analysis", The Journal of applied psychology 89(1), 2004, pp. 127-136.

[5] Armstrong, D. J., Riemenschneider, C. K., Allen, M. W., and Reid, M. F., "Advancement, voluntary turnover and women in IT: A cognitive study of work-family conflict", Information \& Management 44(2), 2007, pp. 142-153.
[6] Atzmüller, C. and Steiner, P. M., "Experimental Vignette Studies in Survey Research", Methodology 6(3), 2010, pp. $128-138$.

[7] B. o. L. Statistics, Occupational Outlook Handbook, U.S. Bureau of Labor Statistics, Washington, DC, 2016.

[8] Backhaus, K. B., "An Exploration of Corporate Recruitment Descriptions on Monster.com", Journal of Business Communication 41(2), 2004, pp. 115-136.

[9] Baum, M. and Kabst, R., "Conjoint implications on job preferences: The moderating role of involvement", The International Journal of Human Resource Management 24(7), 2013, pp. 1393-1417.

[10] Beede, D., Julian, T., Langdon, D., McKittrick, G., Khan, B., and Doms, M., "Women in STEM: A Gender Gap to Innovation", Economics and Statistics Administration, US Department of Commerce 04(11), 2011, pp. 1-11.

[11] Berthon, P., Ewing, M., and Hah, L. L., "Captivating company: Dimensions of attractiveness in employer branding", International Journal of Advertising 24(2), 2015, pp. 151-172.

[12] Bundesagentur für Arbeit, Der Arbeitsmarkt in Deutschland: MINT-Berufe, Statistik/Arbeitsmarktberichterstattung, 2016.

[13] Cable, D. M. and Judge, T. A., "Pay preferences and job search decisions: A person-organization fit perspective", Personnel Psychology 47(2), 1994, pp. 317-348.

[14] Cammann, C., M. Fichman, D. Jenkins, and J. Klesh, The Michigan organizational assessment questionnaire. Unpublished manuscript, University of Michigan, Ann Arbor, 1979.

[15] Carless, S. A. and Wintle, J., "Applicant Attraction: The role of recruiter function, work-life balance policies and career salience", International Journal of Selection and Assessment 15(4), 2007, pp. 394-404.

[16] Castilla, E. J. and Benard, S., "The Paradox of Meritocracy in Organizations", Administrative Science Quarterly 55(4), 2010, pp. 543-676.

[17] Catanzaro, D., Moore, H., and Marshall, T. R., "The Impact of Organizational Culture on Attraction and Recruitment of Job Applicants", Journal of Business and Psychology 25(4), 2010, pp. 649-662.

[18] Chapman, D. S., Uggerslev, K. L., Carroll, S. A., Piasentin, K. A., and Jones, D. A., "Applicant attraction to organizations and job choice: a meta-analytic review of the correlates of recruiting outcomes", The Journal of applied psychology 90(5), 2005, pp. 928-944.

[19] Connelly, B. L., Certo, S. T., Ireland, R. D., and Reutzel, C. R., "Signaling Theory: A Review and Assessment", Journal of Management 37(1), 2011, pp. 39-67.

[20] De Pater, I. E., van Vianen, A. E., Bechtoldt, M. N., and Klehe, U. C., "Employees' Challenging Job Experiences and Supervisors' Evaluations of Promotability", Personnel Psychology 62(2), 2009, pp. 297-325. 
[21] Deloitte, Technology, Media \& Telecommunication Predictions 2016, Deloitte, 2016.

[22] Diekman, A. B., Weisgram, E. S., and Belanger, A. L., "New Routes to Recruiting and Retaining Women in STEM: Policy Implications of a Communal Goal Congruity Perspective", Social Issues and Policy Review 9(1), 2015, pp. 52-88.

[23] Douglas, E. J. and Shepherd, D. A., "Self-employment as a Career Choice: Attitudes, Entrepreneurial Intentions, and Utility Maximization", Entrepreneurial Theory and Practice 26(3), 2002, pp. 81-90.

[24] Drury, B. J., Siy, J. O., and Cheryan, S., "When Do Female Role Models Benefit Women?: The Importance of Differentiating Recruitment From Retention in STEM", Psychological Inquiry 22(4), 2011, pp. 265-269.

[25] Entertainment Software Association, Essential Facts About the Computer and Video Game Industry: Sales, Demographic and Usage Data 2017, 2017.

[26] Farh, J.-L., Hackett, R. D., and Liang, J., "IndividualLevel Cultural Values as Moderators of Perceived Organizational Support-Employee Outcome Relationships in China: Comparing the Effects of Power Distance and Traditionality", Academy of Management Journal 50(3), 2007, pp. 715-729.

[27] Fuesting, M. A. and Diekman, A. B., "Not By Success Alone: Role Models Provide Pathways to Communal Opportunities in STEM", Personality and Social Psychology Bulletin 43(2), 2016, pp. 163-176.

[28] Glass, J. L., Sassler, S., Levitte, Y., and Michelmore, K. M., "What's So Special about STEM? A Comparison of Women's Retention in STEM and Professional Occupations", Social forces; a scientific medium of social study and interpretation 92(2), 2013, pp. 723-756.

[29] Greenhaus, J. H., Parasuraman, S., and Wormley, W. M., "Effects of race on organizational experiences, job performance evaluations, and career outcomes", Academy of Management Journal 33(1), 1990, pp. 64-86.

[30] Guillot-Soulez, C. and Soulez, S., "On the heterogeneity of Generation Y job preferences", Employee Relations 36(4), 2014, pp. 319-332.

[31] Hannon, J. M. and Milkovich, G. T., "The effect of human resource reputation signals on share prices: An event study", Human Resource Management 35(3), 1996, pp. 405424.

[32] Highhouse, S., Thornbury, E. E., and Little, I. S., "Social-identity functions of attraction to organizations", Organizational Behavior and Human Decision Processes 103(1), 2007, pp. 134-146.

[33] Hoobler, J. M., Lemmon, G., and Wayne, S. J., "Women's Managerial Aspirations: An Organizational Development Perspective", Journal of Management 40(3), 2014, pp. 703-730.
[34] Howcroft, D. and Trauth, E. M., "The implications of a critical agenda in gender and IS research", Information Systems Journal 18(2), 2008, pp. 185-202.

[35] Hyde, J. S., "New Directions in the Study of Gender Similarities and Differences", Current Directions in Psychological Science 16(5), 2007, pp. 259-263.

[36] Hyde, J. S., "The Gender Similarities Hypothesis", The American Psychologist 60(6), 2005, pp. 581-592.

[37] Igbaria, M. and Baroudi, J. J., "The Impact of Job Performance Evaluations on Career Advancement Prospects: An Examination of Gender Differences in the IS Workplace", MIS Quarterly 19(1), 1995, pp. 107-123.

[38] Igbaria, M., Greenhaus, J. H., and Parasuraman, S., "Career Orientations of MIS Employees: An Empirical Analysis", MIS Quarterly 15(2), 1991, pp. 151-169.

[39] Joshi, A., Son, J., and Roh, H., "When Can Women Close the Gap?: A Meta-Analytic Test of Sex Differences in Performance and Rewards", Academy of Management Journal 58(5), 2015, pp. 1516-1545.

[40] Judy, K. H., "Agile Values, Innovation and the Shortage of Women Software Developers", Proceedings of the 44th Hawaii International Conference on System Sciences, 2012, pp. 5279-5288.

[41] Kelley, K., "Confidence Intervals for Standardized Effect Sizes: Theory, Application, and Implementation", Journal of Statistical Software 20(8), 2007, pp. 1-24.

[42] King, E. B., Botsford, W., Hebl, M. R., Kazama, S., Dawson, J. F., and Perkins, A., "Benevolent Sexism at Work", Journal of Management 38(6), 2010, pp. 1835-1866.

[43] Konrad, A. M., Ritchie, J. E., Lieb, P., and Corrigall, E., "Sex differences and similarities in job attribute preferences: A meta-analysis", Psychological Bulletin 126(4), 2000, pp. 593-641.

[44] Kram, K. E. and Isabella, L. A., "Mentoring Alternatives: The Role of Peer Relationships in Career Development", Academy of Management Journal 28(1), 1985, pp. 110-132.

[45] Kuhn, K. and Joshi, K. D., "The reported and revealed importance of job attributes to aspiring information technology: A policy-capturing study of gender differences", ACM SIGMIS Database 40(3), 2009, pp. 40-60.

[46] Lievens, F. and Slaughter, J. E., "Employer Image and Employer Branding: What We Know and What We Need to Know", Annual Review of Organizational Psychology and Organizational Behavior 3(1), 2016, pp. 407-440.

[47] Liff, S. and Ward, K., "Distorted Views Through the Glass Ceiling: The Construction of Women's Understandings of Promotion and Senior Management Positions", Gender, Work and Organization 8(1), 2001, pp. 19-36.

[48] Major, D. A., Morganson, V. J., and Bolen, H. M., "Predictors of Occupational and Organizational Commitment in Information Technology: Exploring Gender Differences 
and Similarities", Journal of Business and Psychology 28(3), 2013, pp. 301-314.

[49] Milgram, D., "How to Recruit Women and Girls to the Science, Technology, Engineering, and Math (STEM) Classroom", Technology and Engineering Teacher 71(3), 2011, pp. 4-11.

[50] Monsen, E., Patzelt, H., and Saxton, T., "Beyond Simple Utility: Incentive Design and Trade-Offs for Corporate Employee-Entrepreneurs", Entrepreneurship Theory and Practice 34(1), 2010, pp. 105-130.

[51] Montgomery, D. B. and Rasmus, C. A., "Calibrating MBA Job Preferences for the 21st Century", Academy of Management Learning \& Education 10(1), 2011, pp. 9-26.

[52] Ng, T. W. H., Eby, L. T., Sorensen, K. L., and Feldman, D. C., "Predictors of objective and subjective career success: A meta-analysis", Personnel Psychology 58(2), 2005, pp. 367-408.

[53] Noteboom, C. and Rowland, P., "An Exploration of Anchoring Female Millennial Students to an IS/IT Career Path: The CLASS Model", Proceedings of the 50th Hawaii International Conference on System Sciences, 2017, pp. 5491-5500.

[54] Ohlott, P. J., Ruderman, M. N., and McCauley, C. D., "Gender differences in managers' developmental job experiences", Academy of Management Journal 37(1), 1994, pp. 46-67.

[55] Panteli, A., Stack, J., Atkinson, M., and Ramsay, H., "The status of women in the UK IT industry: An empirical study", European Journal of Information Systems 8(3), 1999, pp. $170-182$.

[56] Panteli, N., "A community of practice view of intervention programmes: The case of women returning to IT", Information Systems Journal 22(5), 2012, pp. 391-405.

[57] Parasuraman, S., Purohit, Y. S., Godshalk, V. M., and Beutell, N. J., "Work and Family Variables, Entrepreneurial Career Success, and Psychological Well-Being", Journal of Vocational Behavior 48(3), 1996, pp. 275-300.

[58] Perlow, L. A., "Putting the Work Back into Work/Family", Group \& Organization Management 20(2), 1995, pp. 227-239.

[59] Perrone, K. M. and Worthington, E. L., JR., "Factors influencing ratings of marital quality by individuals within dual-career marriages: A conceptual model", Journal of Counseling Psychology 48(1), 2001, pp. 3-9.

[60] Quesenberry, J. L. and Trauth, E. M., "The (dis)placement of women in the IT workforce: An investigation of individual career values and organisational interventions", Information Systems Journal 22(6), 2012, pp. 457-473.

[61] Raudenbush, S.W. and A.S. Bryk, Hierarchical linear models: Applications and data analysis methods, Sage, 2002.

[62] Rynes, S. L., Bretz, R. D., and Gerhart, B., "The Importance of Recruitment in Job Choice: A Different Way of Looking", Personnel Psychology 44(3), 1991, pp. 487 521.

[63] Shachaf, P., "Cultural diversity and information and communication technology impacts on global virtual teams: An exploratory study", Information \& Management 45(2), 2008, pp. 131-142.

[64] Shepherd, D. A., Patzelt, H., and Baron, R. A., "'I Care about Nature, but ...": Disengaging Values in Assessing Opportunities that Cause Harm", Academy of Management Journal 56(5), 2013, pp. 1251-1273.

[65] Tharenou, P., Latimer, S., and Conroy, D., "How do you Make it to the Top?: An Examination of Influences on Women's and Men's Managerial Advancement", Academy of Management Journal 37(4), 1994, pp. 899-931.

[66] Thomas, L. T. and Ganster, D. C., "Impact of familysupportive work variables on work-family conflict and strain: A control perspective", Journal of Applied Psychology 80(1), 1995, pp. 6-15.

[67] Thompson, C. A., Beauvais, L. L., and Lyness, K. S., "When Work-Family Benefits Are Not Enough: The Influence of Work-Family Culture on Benefit Utilization, Organizational Attachment, and Work-Family Conflict", Journal of Vocational Behavior 54(3), 1999, pp. 392-415.

[68] Trank, C. Q., Rynes, S. L., and Bretz, J. R. D., "Attracting Applicants in the War for Talent: Differences in Work Preferences Among High Achievers", Journal of Business and Psychology 16(3), 2002, pp. 331-345.

[69] Trauth, E. M., Quesenberry, J. L., and Huang, H., "Retaining women in the U.S. IT workforce: Theorizing the influence of organizational factors", European Journal of Information Systems 18(5), 2009, pp. 476-497.

[70] Tumasjan, A., Strobel, M., and Welpe, I. M., "Employer brand building for start-ups: Which job attributes do employees value most?", Zeitschrift für Betriebswirtschaft 81(6), 2011, pp. 111-136.

[71] Uggerslev, K. L., Fassina, N. E., and Kraichy, D., "Recruiting Through the Stages: A Meta-Analytic Test of Predictors of Applicant Attraction at Different Stages of the Recruiting Process", Personnel Psychology 65(3), 2012, pp. 597-660.

[72] Wang, M.-T. and Degol, J., "Motivational Pathways to STEM Career Choices: Using Expectancy-Value Perspective to Understand Individual and Gender Differences in STEM Fields", Developmental Review 33(4), 2013, pp. 304-340.

[73] Weitzel, T., Eckhardt, A., and Laumer, S., "A framework for recruiting IT talent: Lessons from Siemens", MIS Quarterly Executive 8(4), 2009, pp. 175-189.

[74] Wuhib, F.W. and S. Dotger, Why so few women in STEM: The role of social coping, IEEE, Princeton, NJ, 2014. 